\title{
The Dynamics of Language Shift in Kazakhstan: Review Article
}

\author{
Nurgul Terlikbayeva iD $\varangle{ }^{1}$ and Gulbakhyt Menlibekova (iD 2 \\ ${ }^{1}$ MSc Scholar, Nur-Sultan, Kazakhstan \\ ${ }^{2}$ Doctor of Pedagogical Sciences, Professor, L. Gumilyov Eurasian National University, Nur-Sultan, Kazakhstan
}

$\triangle$ Corresponding Author: Nurgul Terlikbayeva, E-mail: nurgul.terlikbaeva@mail.ru

\section{ARTICLE INFORMATION}

Received: December 18, 2020

Accepted: February 14, 2021

Volume: 3

Issue: 2

DOI: 10.32996/jeltal.2021.3.2.2

\section{KEYWORDS}

Language planning, Kazakhstan, policy, status planning, corpus planning, prestige planning, language acquisition, language shift

\section{ABSTRACT}

In the 90s, language planning in Kazakhstan was hindered because people of other ethnic groups outnumbered Kazakhs. Russian has long been designated as the language of inter-ethnic communication and its status is officially on a par with the state language, Kazakh. The leadership in Kazakhstan avoided taking 'extreme' positions as the stability in the country was at stake, so in order to preserve political stability in the country, the language shift towards Kazakh was delayed. Now in modern Kazakhstan, the number of ethnic Kazakhs has increased which has resulted in positive, albeit slight changes in favour of the Kazakh language. The primary purpose of this review article is to understand the reasons for the slow dynamics of language shift in Kazakhstan. Analysis of the literature and theoretical frameworks by Ruiz and Sonntag and Cardinal sheds light on the dynamics of this shift. One of the contributing factors to its slow dynamics has been the government's support for the bilingual later multilingual language regime. Language planning in Kazakhstan implicitly promotes economic planning. Russian, and more recently English have been favoured as more suitable for human development in Kazakhstan. Another factor associated with the slow dynamics of the language shift is a language's prestige and value. Kazakh is not associated with social success and as such, it remains less prestigious compared to Russian. Based on the evidence, this paper concludes that Kazakhstan is still linguistically dependent on the past state traditions despite being politically independent today. Russian, seen as a language of international communication, in truth, remains intra-national in Kazakhstan.

\section{Introduction}

Kazakhstan has chosen the path of the ex-colonial countries in terms of language planning. The Russian language is an unwanted legacy which Kazakhstan inherited, and being the most Russified country in Central Asia in both ethnic and linguistic terms, Kazakhstan has granted Russian, its colonial language, the status of an official language, equal to the state language. The Government justifies this policy by the fact that after independence the population of Kazakhstan was predominantly made up of ethnic Russians, Russian-speaking Central Asian ethnic groups and European ethnic groups whose combined number exceeded that of ethnic Kazakhs. Full language shift towards Kazakh was delayed to preserve political stability in the country in the early days of the independent Kazakhstan. As a result, official documentation, media in Russian and Russian medium schools have continued to exist as before.

The Kazakh language, especially in the 90s, was regarded as largely symbolic. The majority approved delaying the moves to make Kazakh the primary language but it was not clear how long this would last. Since 1991, a series of language policies have emerged in the country, from which Russian has continued to hold its position. Now, after almost thirty years of independence, there have been tentative steps towards making Kazakh the main language of the country. By means of analysing research papers which review the evolutionary process of language planning in Kazakhstan since independence, this paper aims to find out the reasons for the slow dynamics of language shift in Kazakhstan.

K C AL-KINDI CENTER $\mathbf{R}$ FOR RESEARCH AND R D DEVELOPMENT Your gateway to world-class research

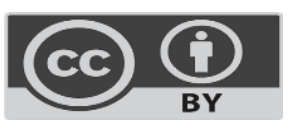

Published by Al-Kindi Center for Research and Development. Copyright (c) the author(s). This open access article is distributed under a Creative Commons Attribution (CC-BY) 4.0 license 
This article presents a historical overview followed by the theoretical framework on language planning and policy. The next section presents and discusses review studies regarding language development in Kazakhstan. The final section presents limitations, implications and a conclusion of the study.

\subsection{Historical Overview}

Kazakhstan was the only country among the post-Soviet countries whose indigenous ethnic group was outnumbered by other ethnicities. In the 90s, there was a far lower Kazakh-speaking population as the first language of the majority of the population was Russian. The language situation in Kazakhstan was affected by the following social, political and economic factors: 1) the unification of Kazakhstan with Russia; 2) the relocation of people from rural communities in various provinces of Russia and Ukraine to Kazakhstan due to agrarian reform; 3) repression (representatives of different nationalities, including Poles, Greeks, Ingush, Chechens, Balkars, Crimean Tatars, and many others were resettled in Kazakhstan under duress; 4) language policy (Russification) aimed at the homogenization of a multilingual society (Suleimenova, 2009, p. 23).

During the colonial time in the 1930s, the language status of Kazakhstan weakened when the new language policy was introduced, and the Kazakh language experienced stagnation lasting seven decades. Due to the ideology on language during those years, the first language of many people living in Kazakhstan, indigenous or not, was Russian. Kurmanbaiuli (2012) notes that because of the change in language policy, in the early 1930s, the principles of language cultivation changed dramatically in the Soviet Union. Kurmanbaiuli (2012) also notes that borrowing from the Russian language would facilitate the convergence of languages of the peoples of the USSR and foster dialogue between scientists. Russian became a kind of language-standard, and linguists were asked to create a common Soviet terminology fund based on Russian (Kurmanbaiuli, 2012, as cited in Davlenov, 2012).

\section{Theoretical Framework}

The problems of language planning and development is relevant in the context of global interaction and dialogue of cultures and civilizations. An American linguist, Einer Haugen, was the first to introduce the term language planning (LP) in the late 1950s. He defines LP as an intentional effort aimed at modification of the linguistic behavior of people who share a common language. Similarly, Cristian (1989) defines language planning as "an organized intervention by politicians, linguists and others in language use and form" (as cited in Ferguson, 2006, p. 1). Rubin (1971) defines LP as an activity targeted at language with established goals, selected means and predicted outcomes in an organized manner (as cited in Burt \& Dulay, 1975). However, according to Fishman (1974) language planning is "the organized pursuit of solutions to language problems, typically at the national level" (p. 79). Cooper does not support this definition and he argues that LP is not an effort aimed at solving language problem rather it is an effort aimed at influencing language behavior (Cooper, 1989, p. 35). These definitions considered together intertwine and form the idea that LP is about language and people manipulation.

In 1969, Kloss proposed two dimensions of planning. The first dimension is corpus planning. According to Kloss (1969), language planning is the attempt of some persons or agencies to modify the shape of the corpus of the language through the introduction of technical terms and a new script. Another dimension according to Kloss is status planning which is aimed at the decision on lowering or raising the status of a particular language. The success of these two categories is interdependent and they both are central to effective language planning (Aktuna, 1995).

Two decades later in 1989, Cooper added one more element; acquisition planning. Cooper defines acquisition planning as a policy that is concerned with the increase of the "number of user-speakers, writers, listeners and readers" (Cooper, 1989, p.33). In other words, acquisition planning is the promotion of language through education and presenting educational materials in a given language. A recent dimension in the field of LP is prestige planning. Haarmann states, "Not only is the content of planning activities important but also the acceptance or rejection of planning efforts". (Haarmann, 1990, p.105). Thus, prestige planning is concerned with the promotion of positive attitudes to the selected language. Prestige planning is central especially when the selected language is restricted to "low-culture functions"; the changes of a selected language's status are socially accepted, if prestige of the promoted language has improved (Deumert, 2000, p. 385). Haarmann views status and corpus planning as productive activity (top-down, i.e. government driven) whereas prestige planning (bottom-up, i.e. individual driven) is receptive. Therefore, he offers "to build up the prestige of the planned products" through four levels which would lead to the success of the LP, namely, activities of individuals, group activities, activities of agencies, governmental activities (Haarmann, 1990, p. 108).

In 1984, Ruiz developed a three-language orientation framework. According to his model, language is viewed as a problem, right and a resource. The problem perspective of language orientation views language diversity in a country as a threat to the unity and cohesion of that nation. The right approach, on the other hand, denotes the maintenance of the civil rights of minority languages and the protection of indigenous languages. In a narrow sense, language as a right concerns human 
rights, i.e. being free from political abuse and possessing the freedom to select the desired language for communication. The third model of Ruiz, language as a resource, means a maintenance of a pluralistic language approach that accentuates the benefits of linguistic diversity. According to Ruiz (1984), LP goals will be determined and realized depending on the language orientation that language planners seek.

A more contemporary theoretical framework in the field based on the concepts of 'state traditions and language regime' belongs to Sonntag and Cardinal (2015). The scholars posit that language policies have political origins and thus studies of language policy choices need to be approached from a political perspective. Through the institutional and historical backgrounds, the theory seeks to discover political actions and factors behind the reasons and ways of language policy choices.

A state tradition is conceived as institutional and regulatory baggage, which 'marks the path that states take in policymaking' (Sonntag and Cardinal, 2015, p. 4). 'Policy pathways may depend on state traditions but policy choices are made at junctions in the path' (Sonntag \& Cardinal, 2015, p. 4). A critical juncture stems from 'political, social, economic, environmental crises' or historical upheavals (Sonntag \& Cardinal, 2015, p.4). Leading the state traditions to the reinvention, critical junctures spawn the emergence of new management models that are 'never completely divorced from the old patterns and traditions in which they were formed' (Sonntag \& Cardinal, 2015 p. 10). Thus, scholars claim that 'state traditions guide policy choices, including language policy choices, along already-established pathways' (Sonntag \& Cardinal, 2015 p. 10).

Language regime is a familiar concept in the field of language planning and policy. Fernand and Grin conceive its notion as synonymous with language planning (Sonntag \& Cardinal, 2015, p.11). Amy Liu defines it as 'the set of rules that' dictate which particular language should be used (as cited in Sonntag \& Cardinal, 2015, p.11). However, Sonntag and Cardinal claim that Amy Liu 'neglects the institutional dimension of a language regime' (p. 11). Instead, they approach the concept of 'language regime' from a historical institutionalism perspective. Hence, the authors contend that 'a language regime refers to language practices as well as conceptions and representations of language and language use as projected through state policies and as acted upon by language users' (Sonntag \& Cardinal p.13). Sonntag also presents the notion of a stable and unstable language regime. 'If the status proffered to users of a particular language matches their anticipations, then we can expect stability' and vice versa (Sonntag \& Cardinal, 2015, p. 14).

\section{Language Planning in Kazakhstan}

In the following chapters reviewing the national and international scientific materials investigating language issues in Kazakhstan since independence, we analyze the process of Kazakhstani language planning and policy. With this in mind, putting the aforementioned language planning dimensions into the Kazakhstani context, and employing theoretical frameworks, we attempt to elaborate on the dynamics of language shift in Kazakhstan.

\subsection{Status Planning}

After independence, in line with its nation-building process Kazakhstan made the development of the Kazakh language a priority. Kazakhstan first established a legal framework as a basis for its future language policies. According to the view of "ethno-nationalism" together with citizenship, the language laws are considered to be critical to claim the power of a titular nation (Matuszkiewicz, 2010, p.2014). Overall, Kazakhstan has adopted three constitutions related to language development. The first constitution adopted in 1993, outlined the role of Kazakh, making it the official state language with Russian the language of inter-ethnic communication. This decision obliged nonnative- speaker citizens of Kazakhstan to learn and speak Kazakh (Kulzhanova, 2012). Karin and Chebotarev (2002) state that the decision on language use had negative effects and the number of native Russian speakers decreased in state organs dramatically. This ambitious policy led to the emigration of ethnic Russians and other Russian speakers (Karin et al., 2002). Consequently, Kazakhstan adopted other two constitutions on language, in 1995 and 1998. Both these constitutions were seen as continued steps to strengthen the status of Kazakh language. However, the second constitution, adopted in 1995, granted Russian equal status in administration and public affairs. It was regarded as a response to the protest and disapproval of ethnic Russians (Karin et al., 2002). Dotton (2016) posits that the action of government to relax the language policies was due to the potential loss of Russian-speaking representatives, which would lead to the loss of competent and skilled workers. This decision was as an indicator of political equity that fostered integration of Russians in the country (Smagulova, 2005).

The aforementioned legislative frameworks gave a way to the adoption of several state programs. Since taking independence, Kazakhstan has adopted three such programs which have outlined the function and development of languages: 1) State Program for the Functioning and Development of Languages in the Republic of Kazakhstan for the Years 1998-2000 (State Program 1998); 2) State Program for the Functioning and Development of Languages in the Republic of Kazakhstan for the Years 2001-2010 (State Program 2001); 3) State Program for the Functioning and Development of 
Languages in the Republic of Kazakhstan for the Years 2010-2020 (State Program 2010).

By outlining the legal framework, Kazakhstan started to implement a series of policy actions. To begin with, the presidency and the chair of both of the houses of parliament were required to be fluent in the state language. Organizations dealing with other state organizations were also required to issue documents in Kazakh (O'Callaghan, 2004). According to the law on languages, officials are obliged to reply to citizens' queries in the "language of the original request" and for number of positions, candidates are expected to speak Kazakh (Smagulova, 2005, p. 32).

According to the 1992 law passed on TV and radio broadcasting in the Republic of Kazakhstan, programs on TV and radio broadcasts, regardless of their forms of ownership, should be primarily in the state language as opposed to in other languages. In turn, "Nazarbayev's decision to move the capital from Almaty to the northern more Russified region of Kazakhstan strengthened the Kazahization process" (Matuszkiewicz, 2010). This decision caused the influx of Kazakh speaking people to the northern region, consequently decreasing the "power base that Russians were holding in the north" (Matuszkiewicz, 2010, p. 216).

Kazakh language school textbooks started to be published, and renaming of cities and streets in a way that reflected Kazakh culture became the norm (Kulzhanova, 2012). These changes did not pass without criticism from non-Kazakhs, who claimed that these actions were discriminatory (Karin et al., 2002). Despite the ambitious decisions on language, implementation of these language policies in Kazakhstan did not fully achieve their targets (Matuszkiewicz, 2010).

Matuszkiewicz (2010) states that scholars investigating language policies criticize the state for "declaring more than it could deliver" (p. 225). Matuszkiewicz (2010) goes on to argue that there was a relative lack of competent staff, and inadequate provisions for language instruction. The scholar also states that the language law and billboards claim that, "It is the duty of every citizen of Kazakhstan to master the state language", however she criticizes the lack of a clear framework and methods on how to do so (p. 226). Similarly, despite the fact that there is a law on TV and radio broadcasting in the state language, electronic mass media fails to meet the requirements due to the lack of content in Kazakh itself (Aksholakova \& Ismailova, 2013). As regards online content, Russian still holds the dominant position (Aksholakova et al., 2013). Fierman (2005) claims that the mere fact of Kazakhstan being an independent state, promoting ideology and increasing the number of ethnic Kazakhs is insufficient to guarantee a high status for the Kazakh language. However, Fierman stresses that Kazakh language's future is bright if Kazakhstan, with its rich natural resources, is able and willing to fund the efforts to popularise it (Fierman, 2005).

According to Fierman (2005), the constant change of government organs in charge of language development is another cause that has halted the implementation of language policy. The scholar states that the local offices in charge of language have been created and abolished periodically, and the chains of commands have shifted (p. 412).

It is important to note that the first President Nazarbayev has been an influential body in promoting the Kazakh language. However, he has always avoided taking "extreme positions" (Fierman, 2005, p. 411). Fulfilling the language claims of Russians

and Russophone citizens of the state was an imperative political act to avert inter-ethnic conflict in the country (Smagulova, 2005).

In 2011, when moves to enhance the status of Kazakh were underway, the language policy of Kazakhstan changed course adopting a cultural program, trilingualism. Nazarbayev (2007) in his address to the nation announced that "Kazakhstan should be seen in the world as highly-educated country whose population uses three languages: Kazakh - the language of the state, Russian - as a language of international communication, and English - the language of successful integration into the global economy". This serious decision on languages has emerged because of globalization. Nazarbayev mentioned the importance of English at the beginning of the 90s, stating, "Without knowledge of English, it is difficult to integrate into the world community, since this language is the global language of information transmission both in the business environment and in everyday communication". Thus, by decree №110 dated 29 June 2011, the President of the Republic of Kazakhstan approved the state program on the use and development of languages in the Republic of Kazakhstan for the years 2011-2020. The main objective of this program is to maintain an effective language policy that will preserve the languages of all ethnic groups living in Kazakhstan and ensure the extensive use of the state language as an important factor in strengthening national unity.

Despite the government's ambitious decision on the development of a multilingual society, there were proponents who did not approve of this decision (Syzdykbayeva, 2016). In her work, Syzdykbayeva states that literary norms of the Kazakh language can be influenced negatively. She backs up her claim by citing the work of Rsaliev whose study proved that the use of English and Russian resulted in the 
"deviation of lexical and grammatical norms" of the Kazakh language (as cited in Syzdykbayeva, 2016, p. 17). Rsaliev's concerns are that Kazakh may qualitatively dimish if the aforementioned tendency continues (Rsaliev as cited in Rizagul, 2016). Additionally, other scientists (Abdurasulov, 2007; Baygozhina, 2007; Laruelle \& Peyrouse, 2007; Rivers, 2002) claim that the use of Russian and English serves as an obstacle to the revitalization of Kazakh. Smagulova (2007) notes that multilingualism is a prevailing public ideology in Kazakhstan. Despite the growing interest in Kazakh, respondents to her research opted mainly for Russian which serves as the main tool to access informational, economic, educational and social resources; yet the overwhelming majority of participants in the research were convinced of the necessity to have mastery in Russian, Kazakh and English (p. 469).

Fierman (2005) points to the fact that in a globalized world, the language of wider communication, he implies Russian, will play an important role across many domains of social communication; therefore, it is unreasonable to expect that Kazakh language will replace the languages of other ethnicities in Kazakhstan. "In areas ranging from advanced science to popular entertainment, Russian is likely to continue to hold a substantial niche" (Fierman, 2005, p. 421).

\subsection{Corpus Planning}

Due to Russian being the dominant language in both the spoken and written communication of Kazakhstanis, until the 90s Kazakh was not widely represented in technology, science, economy official documentation and entertainment, and thus merely fulfilled the role of the language of art and culture (Schatz, as cited in Matuszkiewicz, 2010).

After independence, this problem led Kazakhstani linguists to revise the corpus of Kazakh language meaning that along with status planning, corpus planning has been paralleled in language planning in Kazakhstan. Whether the corpus planning has been successful or not was extensively discussed among Kazakhstani scholars. For instance, Kozhabekova (2003) assumes corpus building to be among the most successful domains of language policy implementation. She ties this success to the collaborative efforts of designated research institutions who have contributed to the development of the rules of Kazakh orthography and to the revision of grammar, punctuation and orthoepics.

Consequently, a research group has created the Kazakh encyclopedic dictionary, and a list of new terminology has been consistently published in state newspapers (Bekturganov as cited in Kozhabekova, 2003). Conversely, Yessimzhanova (2014) criticizes LP stating that, in practice the emerging new terms are only used in written form of mass media or official documents. However, in speech both new terms and their Russian equivalents are used (Yesimzhanova p.71). The scholar concludes that newly created Kazakh alternatives to international words lead to negative effects, in turn leading Kazakh speakers to misunderstand those terms. The translated alternatives are not widely used practically and this triggers communication problems (Yessimzhanova, 2014, p. 72). Similarly, the study by Berkaliev (n. d) revealed educational issues related to newly-created terminology. Berkaliev criticizes the inconsistency in terminology, which caused both learners and teachers confusion (Berkaliev, n. d p.82). Owing to a lack of consensus across society, the State Terminology Commission has reviewed a number of terms such as shaptyrma - meaning a fountain, kuy sandyk - meaning piano, kyltima - meaning balcony. According to the chair, Meldeshov (2017), these terms were not approved and international alternatives were reported to be used instead (as cited in "Kazakh Tilinde", 2017). Meldeshov clarifies that despite the standardized international alternative, the translated versions are still used and remained embedded in daily use (as cited in "Kazakh Tilinde", 2017, para. 5). Another problem that hinders the development of the Kazakh language is code switching (widespread in bilingual countries) which prevails in Kazakh speaking indigenous society. Code switching is a linguistic phenomenon when speakers mix two languages (Reyes \& Moll, 2008).

Kazakh speaking society uses mixed language in order to convey thoughts (Kumar, 2016). It seems that the use of newlycreated terminology hinders understanding; therefore, it is effective to use Russian words when speaking in Kazakh. Furthermore, there is some public debate about the quality of translated books. Suleimenova (2009) criticizes the philologists claiming, "instead of language cultivation they tend to be limited to a direct translation from Russian into Kazakh, violating both the Russian and Kazakh language constructs" (p.21). More importantly, according to experts, the textbook provision in Kazakh language in the field of natural-technical and engineering sciences constitutes merely 10\% (Kabuldinov, 2009, para. 18).

Another hot debate among Kazakhstani scholars pertaining to language development is orthographic reform. In 1917, Nazarbayev signed a decree on the translation of the alphabet from Cyrillic to Latin text. It is important to note here that in the history of Kazakhstan, this will be the third alphabet change. In 1929, the Arabic alphabet was changed to Latin. Later in 1940, the Cyrillic alphabet replaced the Arabic. After the collapse of Soviet Union, Uzbekistan, Turkmenistan and Azerbaijan immediately adopted the Latin script. However, Kazakhstan and Kyrgyzstan could not afford to take this step because of the fact that share of the other ethnicities outnumbered indigenous ethnicities in both countries meaning that alphabet shift was 
regarded as a political threat. However, times have changed and Nursultan Nazarbayev is of the opinion that for the Kazakh language, orthographical modernization is important for the development of economic and political administration, and for the enhancement of international recognition, as well as for taking its place among the top ten oil-producing countries. It is stated that the plan of alphabet shift will have a half- decade preparatory stage, and it is expected to be implemented by 2025. However, Dotton (2016) reveals in her research an absence of legal documents "detailing the conditions, needs, support or implementation of the shift" (p.74). Similarly, Tanayeva (2007) criticizes that policy-making pertaining the alphabet shift is merely limited to decrees.

Politicians and linguists have interpreted the translation from Cyrillic to Latin differently. According to linguists, Latinization distances Kazakhstan from the influence of Russian culture, thus enabling the enhancement of national identity (Dotton, 2016). Kazakh speaking elites support the language shift positing that Latin suits "the Kazakh language's 42 letters" much better than Cyrillic (Tanayeva, 2007, p.81). Khusayn (2007) asserts "In many cases the phonetic nature of Kazakh is not shown by the Cyrillic script" (as cited in Bartlett, 2007, para. 8). As a result, he states, the correct pronunciation is distorted due to the inappropriate representation of particular Kazakh sounds (as cited in Bartlett, 2007, para. 8). If some intellectuals support the Latinization, others are concerned that the shift "might damage the unity and integrity of the multi- ethnic population and strengthen the linguistic divide in Kazakhstan" (Dotton, 2016, p.79). The nationalistic linguists are concerned, stating that if translation of the alphabet occurs, the literary works written in Cyrillic during Soviet times may be lost. We see from history that the consequence of early alphabet translation from Arabic to Cyrillic led to literary work written in Arabic language becoming lost and inaccessible to the greater number of Kazakhs (Dotton, 2016). The attempts at alphabet shift and the development of new terminology are a major part of corpus planning in Kazakhstan, there is not enough scientific evidence on alphabet shift, and these remains open for further discussion.

\subsection{Acquisition Planning}

Implementation of the acquisition of the Kazakh language falls into two phases.

The first phase started immediately after independence. The first stage of Kazakh acquisition was challenging due to the attitudes of the non-Kazakh speaking population towards the Kazakh language. In the early 90s, Russian was highly valued among the majority of the population and the attitude towards learning Kazakh was negative, especially among urban dwellers (Dave \& Sinnott, 2002). At that time of transition, the population of the country still felt connected to the Soviet Union in terms of culture and language; speaking Kazakh was sign of "provincialism" whereas speaking Russian was regarded as being highly cultured (Dave et al., 2002, p. 14). This negative attitude towards learning and speaking Kazakh had taken root among urban ethnic Kazakhs as well. "Up to $40 \%$ of Kazakhs did not speak Kazakh and made no attempts to learn the language" (Smagulova, 2005, p. 31). Smagulova (2005) criticizes several actions driven by the government pertaining to acquisition planning. Her first criticism was the policy forecast, which assumed that language reversal would be attained in a short time period. A further criticism by the same academic was of the government's hurried language policy that did not offer people enough choice. She assumes that a hasty language policy led to the mass emigration of many well-educated, non-Kazakh speaking ethnicities.

The second phase of implementation of acquisition starts with the appearance of so-called modern Kazakhstan, which refers to the years commencing in the 2000s. By this time, non-speakers' attitude towards the Kazakh language were not as negative as they had been in early independence. Everyone understood the necessity of mastering the state language for career purposes, for adaptation and socialization into the modern language realities of the country (Dosova, Imanbetova, Zhumanovaa, \& Zhumasheva, 2016).

In 2005, "Kaztest", a system to evaluate the level of Kazakh language proficiency among Kazakhstani citizens and other foreigners who plan to live and work in Kazakhstani territory was developed by the National Testing Centre of the Ministry of Education and Science of the Republic of Kazakhstan. According to the state program on the development of languages for the years 2011-2020, the share of adults who master the state language is expected to represent $20 \%$ by $2014,80 \%$ by 2017 , and $95 \%$ by 2020 (MES, 2011). By 2017, 50\% of government workers are expected to be certified through Kaztest, and by 2020, this number is expected to reach 100\% (MES, 2011). The acquisition of Kazakh is compulsory for government employees. Kazakh has been taught to administrative and government workers free of charge through government budgets. Research conducted by Aksholakova and Ismailova in 2013, shows that the majority of learners were enthusiastic about learning the state language, however they were dissatisfied with the deductive teaching methods and the everything- shouldbe-as-at-school idea (p.1585). Learners picked up on being treated like schoolchildren as teachers demanded they keep record books, as well as assigning homework and evaluating students on a 5 grade scale (Aksholakova et al., 2013). Analyzing such criticism, one may ascertain that teaching methods for adult learners were not developed and had not even been widely thought through in Kazakh language acquisition planning. Aksholakova et al. (2013) states that the status of the state 
language is confirmed as official but that this is not supported by mechanism which would enhance "the learning and the use" (p. 1586). The scholars posit that the Kazakh language's value is secondary in service communication (Aksholakova et al., 2013).

Language acquisition planning which had initially targeted the adult population later shifted its focus to children (Smagulova, 2005). This coincided with Nazarbayev's (2012) statement that said teaching Kazakh should be targeted at the younger generations rather than at maturer citizens.

In order to promote Kazakh language fluency, the state "trilingual policy" has been enacted. Within the framework of this trilingual education program Nazarbayev Intellectual Schools and some selected public schools provide the following subjects; History of Kazakhstan and Geography, each of which are taught in Kazakh, even in schools with Russian medium instruction.

All schools throughout the country are reported to support the trilingual policy of the government (Mehisto, Kambatyrova $\&$ Nurseitova as cited in Bridges, 2014). Kazakh language teaching hours have increased in Russian medium schools and higher education institutions. However, Abdimanapova (2017) states that secondary Russian medium school students are not motivated to learn Kazakh. The author points to two factors; lack of family engagement and the lack of educational environment, both of which hinder the acquisition of Kazakh. Participants of the study by Mehisto et al. (2014) also expressed their concern about the lack of high-quality Kazakh language teaching materials, which again hinders language acquisition. Moreover, Mehisto et al. (2014) suggests revising the pedagogy that is applicable to trilingual education. Additionally, analyzing the study by Aubakyrov and Dolgopolova (2018) which states that educational institutions still rely on the traditional grammar-translation methods, we assume no modifications in Kazakh language-teaching methods have occurred.

\subsection{Prestige Planning}

Being a part of the Soviet Union, the Kazakh language lost its value and prestige, which led to the declination of the prestige of Kazakh history, identity and culture. As a result, Kazakh language skills were passively acquired and the majority of the Kazakh population acquired Russian. "Kazakh was forced out of the public sphere and business communication", and its 'communicative power' shrank (Smagulova, Suleimenova, 2005, as cited in Agmanova \& Zharkynbekova, 2016, p. 85).

After independence, the government, through various activities such as the celebration of Language Day, and holding Kazakh language olympiads among students, supported the enhancement of positive attitudes of speakers towards the Kazakh language (Kozhabekova, 2003). However, it is important to mention here that prestige planning in Kazakhstan is first explicitly mentioned in the language development program of 2011 -2020. An increase in the prestige of the use of the state language is one of the main objectives of the language development program. It is stated in the program "The implementation of this task will be achieved through the formation and consolidation in the public consciousness of the prestigious image of the speaker of the state language" (MES, 2011). It is also stated that "PR-technologies" are given a primary role in organizing activities to popularize the state language. More importantly, it was stated that the involvement of popular representatives of other ethnic groups than Kazakh who speak the state language is a central part in the formation of a "prestigious image of a bearer of the state language" (MES, 2011).

Despite the government's attempt to support Kazakh language status through various activities, Russian still remains more prestigious. A Russian medium school system continues to exist in Kazakhstan. Every citizen is given the right to select the language medium of the school for their children. The tendency to choose Russian medium schools among majority of Kazakhs is still observed. Aldaberdykyzy (2015) states that the principle cause of this trend is that intellectual capital is highly associated with Russian, and this impacts on the decision of selecting Russian medium schools. Ahn and Smagulova (2016) posit that the decisions of those parents who opt for Russian medium schools indicates a lack of parental commitment to Kazakh language revival.

Smagulova thinks that the cause of this choice is that parents highly value Russian which is regarded as a linguistic capital, through which access to the wider labor-market and to a better quality of life is achieved. From the aforementioned, we conceive the fact that Russian is more preferred than Kazakh as it leads to the achievement of social success. Kazakh is not widely associated with social success and the decision behind the parents who select Kazakh medium instruction is tied merely to national patriotism. 


\section{Discussion}

In order to discover the main reasons for the slow dynamics of language shift in Kazakhstan two theories have been employed as underlying support for our argument. We opine that two theories, namely the theory by Ruiz, 'language as problem, as right, and as resource', and the theoretical framework, 'state traditions and language regime' developed by Sonntag and Cardinal both shed light on the dynamics of the Kazakh language shift.

Literature demonstrates that the Russification policy during the colonial period, which lasted 70 years, seriously affected Kazakhstan both culturally and linguistically. Access to higher education and the labor market required Russian language proficiency so as a result the Kazakh language lost its value and was replaced by Russian. Now Russian is more prestigious and holds a strong position as it is widely used in social spheres in the county. Literature reveals interesting facts about the dynamics of Kazakh considered from the lens of 'language as a right' approach. The right of the Russian language that is outlined in the constitution grants Russian equal status in administration and in public affairs. As literature claims this right encourages the speakers of Russian to continue to stay in their comfort zone, leading them to stay demotivated to acquire knowledge of the state language. Language as a resource also gives light to our understanding of the reasons behind the slow dynamics of Kazakh. Russian as a resource is still highly valued in Kazakhstan. As literature notes, there is a tendency to choose Russian medium schools among the majority of Kazakhs. The cause of this choice is tied to its linguistic value; Russian is regarded as a linguistic capital through which access to the wider labor-market and to a better life is achieved. As such, literature posits that people's motives for using Russian is that they are pursuing goals that are more pragmatic. Moreover, the language policy of Kazakhstan has changed its trajectory, adopting a cultural trilingual policy. The influence of globalization has enhanced the prestige and the role of the English language in Kazakhstan. The ideology adopting the trilingual policy is that English language is regarded as the tool that would successfully integrate the country into the global economy. This pragmatic decision of the political actors changed the traditional approaches of language planning in Kazakhstan, consequently giving way to language pluralism which as researchers state may negatively impact on the prestige of the Kazakh language.

Analyzing the literature from the state tradition and language regime perspective allows us to consider the subject matter on a deeper level. When considering the current language situation in Kazakhstan, we should be aware, as Sonntag pointed out, that 'states have complex historical and normative traditions, reflective of each state's national model, that guide and frame language policies' (Sonntag \& Cardinal). A critical juncture occurred with the collapse of Soviet Union; however, it has not led to decisions that have favored the Kazakh language. Status was awarded to the language, but as the literature indicates, the political actors' deliberate efforts to determine the Kazakh language as the state language were merely tokenistic and not supported by the implementation mechanisms. The role of Russian use is preserved; as such, the domain of its use has not decreased. The state tradition of the Soviet Union is followed extensively and markedly visible in every aspect of societal practice including language in education. To illustrate this, the existence of two languages of instruction in education institutions is a colonial legacy that is visible in present state actions in Kazakhstan. There is often disparity between language policy and language practice when it concerns private sector institutions, trade, entertainment, science and innovation, and even online content, which carry out their own language practices.

Although law protects the status of the Kazakh language, language policy in Kazakhstan follows a bilingual language regime. Literature ties this institutional choice to the demographic situation in the country. Literature has also posited that the leadership in Kazakhstan has avoided taking extreme positions and the assignment of status of official language to Russian was a sign of social stability. Considering this from a historical institutionalism approach, we reveal that policy decisions in Kazakhstan regarding the language regime have replicated the state traditions of the Soviet Union. During the Soviet Union, the use of minority languages was not restricted but such languages only prevailed in a local context. The ideology behind this decision was the preservation of social stability. The current language situation in Kazakhstan is far different compared to that of the Soviet Union. What Kazakhstani policy actors have neglected in terms of past traditions is that sub-state national languages existed in a local realm and in a bigger realm the Russian language suppressed the power of minority languages. Sonntag (2010) posits that language regimes empower particular 'language users more than others to make political claims on the state'. In the Kazakhstani case, the Kazakh language is empowered only on paper. Language users do not act upon the practices and the conceptions of the state language. Foregoing discussions represent the unstable language regime in the country meaning that preferred status of Kazakh language mismatches the expectations of language users.

\section{Conclusion}

The primary purpose of this review has been to understand the reasons for the slow dynamics of language shift in Kazakhstan. One of the contributing factors is the government's support for the bilingual and subsequently the multilingual language regime. Language planning in Kazakhstan implicitly promotes economic planning. 
Russian and lately English have been positioned as resources for human development in Kazakhstan. This situation has had an inevitable impact on the language attitudes of people in Kazakhstan. Another factor associated with the slow dynamics of the language shift is a language's prestige and value. Despite the empowerment of the Kazakh language by legal documents, the influence of Russian remains clear across the country. Kazakh is not synonymous with social success and as such, it remains less prestigious compared to Russian. The tendency to choose Russian medium schools among the majority of Kazakhs is evidence of this. Russian competes effectively with the state language in every domain of society. Kazakhstan is still linguistically dependent on the past state traditions despite being politically independent today. Russian being reported as a language of international communication, in truth, remains the language of intra-national communication in Kazakhstan.

Despite the significant aforementioned findings, this research, however, has potential limitations. The methodology of our study included analysis of literature review. We relied more on secondary research study and less on primary research due to the scarcity of original studies. However, this limitation will inform future researchers on the need to conduct primary research on subject matter to gain valid data.

This study has shed a light on the trends of the language development in Kazakhstan and revealed the fact that language have become politicized and it has been employed as mechanism in meeting the economic and political needs of the country. Thus, this study emphasizes the need of conducting more research on language planning and development from social, political, economic and linguistic perspective to obtain rigorous data. This scholarly work can be used as a guideline for researchers and linguists in analyzing the current state of the language situation in in the country. Another major implication is that this paper addresses the need of the development of LP as a scientific discipline; integration of LP into academic programs generates scientific collaborations and ongoing interaction with information so that stakeholders could be aware and informed of the language trends and situations in Kazakhstan.

Funding: This research received no external funding.

Conflict of Interests: The authors declare no conflict of interest.

\section{References}

[1]. Abdimanapova, L. (2017). Motivation of Students in Russian Medium Groups to Learn Kazakh in CLIL Approach. Nu.Edu.Kz, 2.

[2]. Ahn, E. S., \& Smagulova, J. (Eds.). (2016). Language Change in Central Asia (Vol. 106). Walter de Gruyter GmbH \& Co KG.

[3]. Aksholakova, A., \& Ismailova, N. (2013). The Language Policy of Kazakhstan and the State Language in Government Service. Procedia Social and Behavioral Sciences, 93, 1580-1586.

[4]. Ashimov, Z. (2005). K voprosu o stanovlenii gosudarstvennogo yazyka v Kazakhstane [On the formation of the state language in Kazakhstan]. Vestnik, 13. http://www.nkzu.kz/files/vestnik/vestnik 1\%2830\%29\%202016.pdf

[5]. Aubakirov, N. M., \& Dolgopolova, A. A. (2018). The Communicative Language Teaching Method in Teaching the Kazakh Language to Russian-Speaking Technical Students in Kazakhstan. Higher Education in Russia, 27(8-9), 152- 158.

[6]. Baker, C. (1988). Key issues in bilingualism and bilingual education. Clevedon, Angleterre: Multilingual Matters.

[7]. Baldauf, R. (1984). The Materials Development Problem in Planned Language Modernization Programs. https://eric.ed.gov/?id=ED246665

[8]. Baldauf, R. B. (2006). Rearticulating the Case for Micro Language Planning in a Language Ecology Context. Current Issues in Language Planning, 7(2-3), 147- 170. https://doi.org/10.2167/cilp092.0

[9]. Balgazina, B. (2007). Dinamika Yazykovoy Situatsii v Postsovetskom Kazakhstane [Dynamics of the Language Situation in postSoviet Kazakhstan]. Kul'tura Narodov Prichernomor'ya.

[10]. Bartlett, P. (2007, September 4). Kazakhstan: Moving Forward with Plans to Replace Cyrillic with Latin Alphabet. https://eurasianet.org/kazakhstan-moving-forward-with-plan-to-replace-cyrillic- with-latin-alphabet

[11]. Berkaliev, Z. (n.d.). Mathematics Education Issues in post-Soviet Kazakhstan: An International Perspective. http://math.unipa.it/ grim/21_project/21_charlotte_BERKALIEVPaperEdit.pdf

[12]. Bridges, D. (2014). Educational reform and internationalization: the case of school reform in Kazakhstan. Cambridge, United Kingdom: Cambridge University Press.

[13]. Cardinal, L., \& Sonntag, S. K. (Eds.). (2015). State traditions and language regimes. McGill-Queen's Press-MQUP.

[14]. Coleman, J. A. (2006). English-medium teaching in European higher education. Language Teaching, 39(1), 1-14. https://doi.org/10.1017/s026144480600320x

[15]. Collier, V. P. (1992). A Synthesis of Studies Examining Long-Term Language Minority Student Data on Academic Achievement. Bilingual Research Journal, 16(1-2), 187-212.

[16]. Dave, B., \& Sinnot, P. (2002). Demographic and language politics in the 1999 Kazakhstan census. Washington, D.C.: National Council For Eurasian And East European Research. https://www.ucis.pitt.edu/nceeer/2002-815- 01g-Dave.pdf

[17]. Davlenov, E. (2012). Tolko na Mertvyh Yazykah ne Rozhdajutsja Terminy [Terminology is not Created only in Dead Languages]. http://uralistica.com/profiles/blogs/tolko-na-mertvyh-jazykah-ne- rozhdajutsja-terminy

[18]. Demographic and Language Politics in the 1999 Kazakhstan Census | NCEEER. (2002). https://www.nceeer.org/papers/110demographic-and-language-politics-in-the-1999-kazakhstan-census.html

[19]. Determinants of Language Choice among Bilingual Students in Kazakhstani Educational Institutions. (2019, February 7). https://articlekz.com/en/article/22331 
[20]. Deumert, A. (2000). Language planning and policy. Introducing sociolinguistics, 384- 418.

[21]. Dotton, Z. (2016). Language Policy and Language Planning in Kazakhstan: About the Proposed Shift from the Cyrillic Alphabet to the Latin Alphabet. Arizona.Edu.

[22]. Ferguson, G. (2006). Language planning and education. Edinburgh University Press.

[23]. Fierman, W. (2005). Kazakh Language and Prospects for its Role in Kazakh "Groupness." Ab Imperio, 2005(2), $393-423$. https://doi.org/10.1353/imp.2005.0065

[24]. Fierman, W. (2006). Language and Education in Post-Soviet Kazakhstan: Kazakh- Medium Instruction in Urban Schools. Russian Review, 65(1), 98-116.

[25]. Fierman, W. (2009). Language vitality and paths to revival: contrasting cases of Azerbaijani and Kazakh. International Journal of the Sociology of Language, 2009(198).

[26]. Gill, S. K. (2005). Language policy in Malaysia: Reversing direction. Language Policy, 4(3), 241-260.

[27]. Haugen, E. (1966). Dialect, Language, Nation. American Anthropologist, 68(4), 922- 935. https://doi.org/10.1525/aa.1966.68.4.02a00040

[28]. Hopson, K. (2007). Mott Children's Hospital ranked top children's hospital in state by Child Magazine. University of Michigan Health System. http://www.med.umich.edu/opm/newspage/ 2007/childmag.aspx

[29]. Hyett, N., Kenny, A., \& Dickson-Swift, V. (2014). Methodology or method? A critical review of qualitative case study reports. International Journal of Qualitative Studies on Health and Well-Being, 9(1), 23606. https://doi.org/10.3402/qhw.v9.23606

[30]. Jung, S. K., \& Norton, B. (2002). Language planning in Korea: The new elementary English program. Language policies in education: Critical issues, 245-265.

[31]. Kabuldinov, Z. (2014, March 21). A Vuz i nine tam... . [A Higher Education Institute is there...]. https://camonitor.kz/11285-.html

[32]. Kambatyrova, A., \& lyldyz, L. (2019). Vestnik KazNU. Seriya pedagogicheskaya. http://bulletin-pedagogic- sc.kaznu.kz/index.php/1ped/article/view/313

[33]. Kaphesi, E. (2003). The influence of language policy in education on mathematics classroom discourse in Malawi: the teachers' perspective. Teacher Development,7 (2), 265-285.

[34]. Kazakh tilinde on segiz min termin bekitilgen. (2017, April 4). Kazakh Tilinde On Segiz Min Termin Bekitilgen. [Eighteen Thousand Terms are Fixed in the Kazakh Language]. http://tilalemi.kz/article/540-.html

[35]. Kolstø, P. (1998). Anticipating demographic superiority: Kazakh thinking on integration and nation building. Europe-Asia Studies, 50(1), 51-69.

[36]. Kulzhanova, A. (2012). Language Policy of Kazakhstan: An Analysis. Central European University.

[37]. Kumar, N. (2016). Memlekettik Tilding Kosegesi Kashan Kogeredi? [When Will the State Language Prosper?]. http://old.baq.kz/storage/5d/5dccfc09984b20409e153eac4ed45d54.pdf

[38]. Laakso, J. (2001). The Finnic languages. Circum-Baltic Languages, 1, 179-212.

[39]. Matuszkiewicz, R. (2010). The language issue in Kazakhstan - institutionalizing new ethnic relations after independence. Economic and Environmental Studies, 10(2), 211-227.

[40]. MES. (2011). The state program of language development and functioning for 2011- 2020. http://prokuror.gov.kz/rus/dokumenty/gosudarstvennyy-yazyk/o- gosudarstvennoy-programme-razvitiya-ifunkcionirovaniyayazykov-v

[41]. Moriarty, M., \& Pietikäinen, S. (2011). Micro-level language-planning and grass-root initiatives: a case study of Irish language comedy and Inari Sámi rap. Current Issues in Language Planning, 12(3), 363-379. https://doi.org/10.1080/14664208.2011.604962

[42]. Ovando, C. J. (2003). Bilingual Education in the United States: Historical Development and Current Issues. Bilingual Research Journal, 27(1), 1-24.

[43]. Padilla, A. M. (1990). Bilingual Education: Issues and Strategies. Sage Publications/Corwin Press, 2455 Teller Road, Newbury Park, CA 91320.

[44]. Reyes, I., \& Moll, L. C. (2008). Bilingual and Biliterate Practices at Home and School. The handbook of educational linguistics, 147.

[45]. Rsalieva, N. (2014). Kazakhstandagy Ushtugurly Til Ideologiyasynyn Positivti zhane Negativti Tustary [Positive and Negative Sides of Trilingual Ideology in Kazakhstan]. Paper presented at International Conference Building Cultural Bridges, Kaskelen Almaty: Print World, 447-457.

[46]. Ruíz, R. (1984). Orientations in Language Planning. NABE Journal, 8(2), 15-34. doi: 10.1080/08855072.1984.10668464

[47]. Schlyter, B. N. (2013). Sociolinguistic changes in transformed Central Asian societies. Languages in a globalizing world, 157. DOI:10.1017/CBO9780511613739.011

[48]. Seran Doğançay Aktuna. (1995). Language Planning and Education: An Intertwined Matrix. Dilbilim Araştırmaları Dergisi, 6, 77-95. http://dad.boun.edu.tr/issue/4535/313064

[49]. Shamim, F. (2008). Trends, issues and challenges in English language education in Pakistan. Asia Pacific Journal of Education, 28(3), 235-249.

[50]. Shindaliyeva, M. (2014). Razvitiye Knigoizdaniya v Kazakhstane [Book Publishing Development in Kazakhstan]. https://almavest.ru/ru/archive/758/2347

[51]. Sinyachkin, V. P., \& Sinyachkina, N. L. (2018). Multilingualism in the Republic of Kazakhstan: viewpoint from the Outside. Polylinguality and Transcultural Practices, 15(3), 445-460. https://doi.org/10.22363/2618-897x-2018-15-3-445-460

[52]. Smagulova, J. (2005). Chapter 4: On the Likelihood of Language Conflict in Kazakhstan. http://www.langdevconferences.org/publications/2003

[53]. Smagulova, J. (2008). Language Policies of Kazakhization and Their Influence on Language Attitudes and Use. International Journal of Bilingual Education and Bilingualism, 11(3-4), 440-475. https://doi.org/10.1080/13670050802148798

[54]. Sonntag, S. K., \& Cardinal, L. (2015). State traditions and language regimes: A historical institutionalism approach to language policy. Acta Universitatis Sapientiae, European and Regional Studies, 8(1), 5-21. 
[55]. Sukumane, J. (2000). Issues in Language Policy and Planning: the Case of Namibia. Studies in the Linguistic Sciences, 30(2).

[56]. Suleimenova, E. (2009). Ocherk Yazykovoy Politiki i Yazykovoy Situatsii v Kazakhstane [Essay on the Language Policy and Language Situation in Kazakhstan]. Russian Language Journal: 21. http://www.jstor.org/stable/43669158

[57]. Tanayeva, L. (2007). The Politics of the Latin alphabet in Kazakhstan. ALPPI Annual of Language \& Politics and Politics of Identity, 1(01), 79-84.

[58]. Thomas, Gary. (2011). A Typology for the Case Study in Social Science Following a Review of Definition, Discourse, and Structure. Qualitative Inquiry, 17(6), 511- 521.

[59]. Tollefson, J. W. (2012). Language policy in a time of crisis and transformation. In Language policies in education (pp. 23-46). Routledge.

[60]. Yeshimbetova, Z., \& Demeuova, A. (2012). Kazakhstanskoye «Trekh"yazychiye» — Unikal'naya Formula YAzykovoy Politiki [Kazakhstan's "Trilingualism" - A Unique Formula of Language Policy]. Novosibirsk: SibAK. https://sibac.info/conf/innovation/xi/28809

[61]. Yin, R. K. (1981). The Case Study Crisis: Some Answers. Administrative Science Quarterly, 26(1), 58. https://doi.org/10.2307/2392599

[62]. Zhumanova, A. Z., Dosova, B. A., Imanbetov, A. N., \& Zhumashev, R. M. (2016). Language Politics in the Republic of Kazakhstan: History, Problems and Prospect. International Journal of Environmental and Science Education, 11(11), 4241-4253 